\title{
BETWEEN THE INFLUENCE OF CUSTOMARY, DUTCH, AND ISLAMIC LAW Jaksa Pepitu and Their Place in Cirebon Sultanate History
}

\section{Tendi; Djoko Marihandono; Abdurakhman}

University of Indonesia, Jakarta

email:tendi@ui.ac.id

\section{Abstract}

The field of law is an interesting matter in the study of Indonesian bistory. The meddling of the various elements of culture and tradition due to political dynamics and power in the nation's history, making law in Indonesia one type of bybrid entity. The interference of the law was not only seen from its legal products, but also from the bodies given the responsibility to enforce the law at that time. One of the prosecutors' agency that had existed in the past was Jaksa Pepitu. This study aims to reveal the origins of the Jaksa Pepitu, elaborate on their works in the field of law in Cirebon environment, and describe the legal influences that contributed to the color of this collegial council. By way of historical research methodology and narrative approach, it can be seen that the prosecutor's council is the agency essential in the practice of law. They were linked to Cirebon princes and can be appointed through VOC approval. In addition, the actions of the prosecutors can be seen from the position, independence, and authority they bave. The various things surrounding the Jaksa Pepitu indicate that it is legal institution influenced by customary, Western and Islamic laws.

Bidang bukum menjadi hal yang menarik dalam kajian sejarah Indonesia. Percampuran pelbagai unsur budaya dan tradisi akibat adanya dinamika politik dan kekuasaan dalam perjalanan bangsa, membuat bukum di Indonesia menjadi salah satu jenis hukum yang bersifat bybrid. Percampuran 
bukum itu tidak hanya dilihat dari produk bukum yang dibasilkan, namun juga dapat ditelisik dari badan yang diberi tanggungjawab untuk menegakean bukum pada masa itu. Salah satu badan jaksa yang pernah eksis di masa lalu adalah Jaksa Pepitu. Studi ini bertujuan untuk mengungkapkean asal muasal Jaksa Pepitu, menguraikan kiprahnya dalam bidang bukum di lingkungan Cirebon, dan mendeskripsikan pengarub-pengarub bukum yang turut memberi warna dewan kolegial ini. Dengan metodologipenelitian sejarah dan pendekatan naratif yang dilakukan, dapat diketabui bahwa dewan jaksa itu merupakan badan penanggung jawab bidang bukum. Mereka memiliki keterkaitan dengan para pangeran Cirebon dan dapat diangkat dengan persetujuan VOC. Selain itu, kiprah para jaksa ini dapat dilibat dari posisi, independensi, dan wewenang yang mereka miliki. Adapun pelbagai hal yang mengitari Jaksa Pepitu menunjukkan babwa mereka ini adalab badan yang dipengarubi oleb bukum adat, Barat, dan Islam.]

Keywords: Jaksa Pepitu, Islamic law, customary, Cirebon, VOC.

\section{A. Introduction}

The legal life of the Indonesian people has experienced a long journey since many centuries ago. Local law (referred to as customary law), which later mixes with European law and religious law, forms a legal system that exists in contemporary Indonesian. Customary law that derived from the preservation of the rules and local wisdoms of the people in the Archipelago, can collaborate with European law because of the historical factors of Indonesia that were once colonized by Dutch East Indies Company (Vereenigde Oostindische Compagnie or also called as VOC) and the colonial Dutch East Indies government. Meanwhile, in relation to religious law, it depends on the condition of Muslims in Indonesia as the majority people. It is very influential to the legal aspects because a lot of Islamic Shari'a was implemented by a lot of people, starting from family and marriage matters, to inheritance distribution.

The amalgamation of the customary, Western, and Islamic laws did not happen suddenly, but gradually over time in line with the sociopolitical development of the Indonesian people. One important phase of those law amalgamtion took place in the seventeenth and eighteenth centuries, when the VOC began to embed its influence and establish its 
power in the Archipelago after successfully mastering Maluku and Sunda Kelapa and developing its power. Since then, little by little the whole Java can be subdued by the Compagnie, either by agreement or war.

The Cirebon and Priangan territories were the first VOC colonies obtained from Mataram after the inland country entered into an alliance agreement since many attacks from its enemies until Mataram palace was destroyed in $1677 .{ }^{1}$ Through a series of agreements and contracts on military assistance provided by the VOC to Mataram, the Cirebon and Priangan regions actually became the property of the Company in the early eighteenth century. To cover the cost of the war and earn profits from the land they had just achieved, the Compagnie began to explore the place by approaching local authorities and binding them in a series of agreements and mutually beneficial relationship.

The agreement that made between the Cirebon Princes and VOC officials is not only focused on the economic agreement, but also on understanding of social and legal matters. If economic problems are related to various agricultural products that can be monopolized by the VOC, then social and legal issues are related to various aspects of people's lives and regulations that can maintain the harmony. So, because considering its security area aspects, and also observing the conflict inclination between each Cirebon Princes, the VOC appointed representatives of the palace who could be involved to be responsible for legal issues that exist in the region. The delegates appointed from each of the Cirebon Princes and with the total number of seven mantris who were given the responsibility of to always takings care of legal issues. Due to their work, the seven mantri are known as Jaksa Pepitu. In carrying out their duties as executors of legal authority, this council is guided by the customary law book called as pepakem. ${ }^{2}$

The existence of the mantri in a collegial body has continued since 1685 due to legal cases that have occurred from time to time. But their position became dilemmatic because by being a member of the prosecuting council in charge of Padu affairs, sometimes they

1 H.J. de Graaf, Runtubnya Istana Mataram (Jakarta: Grafiti Pers, 1987), pp. 189-96.

2 Sobana Hardjasaputra and Tawalinuddin Haris (eds.), Cirebon Dalam Lima Zaman: Abad ke-15 hingga Pertengahan Abad ke-20 (Bandung: Dinas Pariwisata dan Kebudayaan Provinsi Jawa Barat, 2011), p. 110. 
have to be confronted with the interests of their lords, the Cirebon Princes. In addition to these vacillations, the attitudes and decisions taken by the prosecutors in determining a case are certainly based on a guideline considered authoritative by both the government and the community. Many questions arises to ask the origins of the law enforcer, the basic guideline for the prosecutors, the influences of some law to the body of Jaksa Pepitu, the place of them in legal history, etc.

These questions can only be answered with a deep legal historical study of Cirebon at that time. There were a number of scholars who were interested in the discourse and dynamics of the aspects of Cirebon law in the colonial time, and the three of which were the most intense were Hazeu, Hoadley, and Satibi. In a study conducted by Hazeu, he described the local Cirebon book called Pepakem in two languages, Javanese and Dutch. In his work, the Cirebon local legal manuscript has been arranged very neatly and arranged in a modern legislative system. ${ }^{3}$ While the study conducted by Hoadley related to the aspects of Cirebon law, it can be said to be the most complete work as he can describe the judicial competition in the Cirebon region since the area was ruled by the three princes of Panembahan Girilaya descents until the colonial era. ${ }^{4}$ Meanwhile, Satibi, with his most recent studies, reviewed the legal products that were born in the eighteenth century by focusing on aspects of Islam in the law book. ${ }^{5}$ The three results of the research almost converge on the same conclusion, that the modernization and Islamization of law in Cirebon cannot be separated from the role and efforts made by the VOC. It focuses on the study of existing legal products such as legal guidance or legal book.

However, the three works did not describe what the party compiling and implementing the contents of the legal book. This study seeks to see the legal field from the enforcement agent media, i.e. the Jaksa Pepitu. This research emphasizes on the figures fulfilling the task of the prosecutor's

3 G.A.J. Hazeu (ed.), “Tjeribonsch Wetboek van het jaar 1768 (Pěpakĕm Tjĕrbon)", VBG, vol. 55 (1905), pp. 1-187.

4 Mason C. Hoadley, Selective Judicial Competence: The Cirebon-Priangan Legal Administration, 1680-1792 (Ithaca, N.Y: Southeast Asia Program Publication, Cornell University, 1994).

5 Ibi Satibi, "Produk Pemikiran Hukum Islam di Kerajaan Islam Cirebon Abad ke-18 M: Studi atas Kitab Hukum Adat Pepakem", Saintifika Islamica: Jurnal Kajian Keislaman, vol. 1, no. 02 (2017), pp. 110-38. 
council, and find out the trajectory of the judicial body in Cirebon's legal history. A number of questions are formulated here. First, who was the Jaksa Pepitu and what was the origin of the agency? Second, what was the dynamics and journey of this body in the history of Cirebon? Third, were there any influences coming from the elements of customary, Western or Islamic law on this collegial council?

This study will construct the role of the Jaksa Pepitu existed in the historical memory of the Cirebon people recorded as an agency that was influenced by customary, the West, and Islamic law. As the device in the judiciary, the prosecutor is not merely a complement, but also one of important aspects that contribute to determine the session course of the court. If in the contemporary era, prosecutors have a role as officers in submitting accusations or legal charges against people allegedly violated the law in a court process, ${ }^{6}$ then in the late seventeenth and eighteenth centuries, the role of the prosecutor council referred to as the Jaksa Pepitu was far broader because they had responsibility for legal affairs in the Cirebon area. ${ }^{7}$ By absorbing the role that has been demonstrated by the Jaksa Pepitu in the history of the Cirebon judiciary, the author considers that the performance carried out by the prosecutors by taking various elements for better legal purposes can serve as role models in the implementation of the justice system in Indonesia.

Implementing the principles of historical research method, this study tries to trace the historical evidence through various records of archival and writing documents, which are then verified, criticized, and confirmed with other sources, so as to systematically draw the result of the study.

${ }^{6}$ In Chapter I, article 1, point 6a, it was written that the Prosecutor was an official authorized by the law to act as a public prosecutor and carry out a court decision that had obtained permanent legal force. Undang-Undang Number 8 of 1981 concerning the Criminal Procedure Code (or called in Indonesia as KUHAP).

7 Mason C. Hoadley, Islam dalam Tradisi Hukum Jawa \& Hukum Kolonial, trans. by Jamil Gunawan (Yogyakarta: Graha Ilmu, 2008), p. 332.Legal responsibility can be given to Jaksa Pepitu because the seven members of this council are one entity whose members come from various elements of Cirebon's authority who have competence in the field of law. Hoadley, Selective Judicial Competence, p. 18. 


\section{B. The Origins of Jaksa Pepitu}

Jaksa Pepitu is the prosecutor's council that has existed since the time of the division of the Cirebon Sultanate into three powers until the influence of the VOC into the realm of law and court. Members of this prosecutor's office are the best mantri (local leader) from a number of regions of the Cirebon subordinates. Then, the competence and experience can be regarded as a benchmark used as the most important consideration for their election process as prosecutors. The panel of the judiciary consisted of seven prosecutors chosen by three Cirebon ruler princes descendants of Panembahan Girilaya, namely Sultan Sepuh, Sultan Anom, and Panembahan Cirebon, to receive complaints or lawsuits, conduct investigations, and conduct hearings in a court of Cirebon kingdom.

Padu case is a matter related to the wider community and is not related to the authorities. In this context, it is generally understood that the case existed in the realm of the court at the time of the kingdoms of pre-colonial divided into two parts, namely: (1) Padu case or cases no relation at all with the king; and (2) Pradata case or case matters which are matters related to the king. In Mataram, in Sultan Agung era, these two courts are still running. ${ }^{8}$ Likewise in Cirebon, before the VOC penetrated deeper into the legal aspects of the people, the Cirebon princes were still using padu and pradata systems. ${ }^{9}$

It is not known exactly when the first time Jaksa Pepitu in the Cirebon Sultanate was formed. His presence was not known at this time when Sri Mangana (Prince Walangsungsang or Cakrabuana) and Sheikh Syarif Hidayatullah (Sunan Gunung Jati) came to power. During

8 Abdul Halim, Peradilan Agama dalam Politik Hukum di Indonesia: Dari Otoriter Konservatif menuju Konfigurasi Demokratis-Responsif(Jakarta: Raja Grafindo Persada, 2000), p. 39.

${ }^{9}$ Hoadley, Selective Judicial Competence, p. 12. Court grouping into these two types can occur because of the influence derived from the use of various types of law that developed in the archipelago. A Padu legal source is the original law of the Nusantara community, while the Pradata law comes from Hindu law. In addition, the Padu law is generally not written because this relates directly to the king's figure, while the Pradata law is neatly recorded in a legal book which is then used as a guide in the execution of the court. See, Raden Tresna, Peradilan di Indonesia: Dari Abad ke Abad (Jakarta: Pradnya Paramita, 1978), p. 16. 
the leadership of Sri Mangana, Cirebon was still in the Sunda Pajajaran Kingdom and then all aspects of the lives of its people were connected to a kingdom that had not yet converted to Islam, including in the legal aspects. Whereas during the period of Syarif Hidayatullah's leadership, the Islamic civilization that had been initiated since the days of Sri Mangana began to enter the state field. At that time, legal affairs were handed over to Shaykh Abdurakhim, a prosecutor who came from the Middle East. Because Shaykh Abdurakhim dedicated himself and his life to being responsible in law in the Cirebon Sultanate, he was known as the Prince Kejaksan. This figure plays a central role in the justice problem because in the hands of the Prince Kejaksan, the legal case in Cirebon was decided. ${ }^{10}$ Thus, even though the law from the Pajajaran main kingdom which was non-Muslim was still used, the law in the first period of the Cirebon Sultanate had been infiltrated by Islamic elements because the Prince Kejaksan, as the principal prosecutor of the kingdom, was a devout Islamic cleric so that in various decision making what he did always pay attention to Islamic values.

Even so when the reign of government has turned to Panembahan Ratu I, the legal aspect in Cirebon, its assigning and controlling, is still single on Pangeran Kejaksan relatives hands. This continued to occur until the reign of Panembahan Ratu II, when the Cirebon Prosecutor was held by Jaksa Sumirat who was the son of Patih Seminingrat and still a descendant of Prince Panjunan or Prince Kejaksan brother. Regarding this matter, in the KCR 04 manuscript, it is explained that: ${ }^{11}$

"Papatihe Panembahan mangkin Ki Patih Seminingrat Yaiku estu putraneng Ki Rudamada mau Winuri ing tunggake kasemi mila pinaparaban Seminingrat wau Ramaning Jaksa Sumirat Tunggal boronjot Panjunan kang kakandbi ing linggibe sang nata ..."

And as Pepatih, appointed (by the Panembahan), Ki Patih Seminingrat who is the son of Ki Rudamada. He also replaced the position of the father as Patih Cirebon before. The Seminingrat nickname is because he

10 Shaykh Abdurakhim was the son of Shaykh Datuk Kahfi, brother of Shaykh Abdurakhman and Syarifah Baghdad who was the wife of Sunan Gunung Jati.

11 Muhamad Mukhtar Zaedin and Panji Darussalam (eds.)Bambang Irianto and Tarka Sutarahardja (trans.), Sejarah Cirebon: Naskah Keraton Kacirebonan: Alih Aksara dan Bahasa Teks KCR 04 (Yogyakarta: Deepublish, 2013), p. 21. 
is the father of the Jaksa Sumirat. They are still the family of Panjunan.

Changes in the legal field occurred when the Cirebon Sultanate was divided into three powers, being: Kasepuhan, Kanoman, and Panembahan. At that time, the kingdom's prosecutors were no longer single, but consisted of seven prosecutors from each palace. In a signed cooperation agreement between the Cirebon Princes and the VOC, it was known that the Jaksa Pepitu membership consisted of seven prosecutors, three of whom were from Kasepuhan, two from Kanoman, and two from Panembahan. ${ }^{12}$ Regarding the number of prosecutors, there was its own uniqueness which was recorded in the Layang Ubaya rules issued around 1690. The Jaksa Pepitu whose members were taken from the subordinate leaders of the Cirebon Prince turned out to be not seven people. If seen in the regulation, overall all the instructions of the Cirebon Princes amounted to twelve people, it could even be thirteen if Ki Arya Raksa Dipura was the author of the regulation counted as one of them. For priyayi under the coordination of Kasepuhan, consisting of: (1) Ki Demang Raksa Dimanggala; (2) KiTumenggung Raksa Winata; (3) Ki Ngabehi Suraga Marta; (4) Ki Ngabehi Dimarta; and (5) Ki Ngabehi Sura Gantaka. As for the elite group from the Kanoman region, namely: (1) Ki Tumenggung Mangun Nagara; (2) Ki Wadoji; (3) Ki Demang Niti Nagara; (4) Raden Ngabehi Dipa Nagara, and (5) Ki Rangga Karta Nagara. Meanwhile, there were only two local leaders under Panembahan, namely: (1) Ki Tumenggung Niti Praya, and (2) Ki Demang Wirat Maka. ${ }^{13}$ Of the twelve leaders of the count, which was recorded as the next Jaksa Pepitu just seven people.

Hoadley revealed that it can happen because of the possibility that the whole priyayi and wadana mentioned in the text Layang Ubaya qualify as a member of the Jaksa Pepitu, but every person is not always active as a prosecutor. The total number of officials (who can be appointed as

12 Hazeu (ed.), "Tjeribonsch Wetboek van het jaar 1768 (Pëpakĕm Tjërbon)”; T.D. Sudjana (tran.), Papakem Jaksa Pipitu (Jakarta: Departemen Pendidikan dan Kebudayaan, Proyek Penerbitan Buku Sastra Indonesia dan Daerah, 1981).

13 Layang Ubaya can be seen in J. Brandes, "Eenige Officiele stukken met betrekking tot Tjerbon", TBG, vol. 37 (1894), pp. 448-9; Mason C. Hoadley and M.B. Hooker, An Introduction to Javanese Law: A Translation of and Commentary on the Agama (Tucson, Arizona: University of Arizona Press, 1981), pp. 258-60. 
prosecutors) registered in Layang regulation is more than a half including seven people needed for the formation of the prosecutor's council responsible for the law. Next to the seven chosen people, other officials function as reserves, so that if there is one member affected by the disease or even dies, the allocated quota of prosecutors can remain fulfilled. ${ }^{14}$

Without prejudice to other opinions, it seems that the number of seven people determined for the Jaksa Pepitu formation is based on a number of certain conditions. Indeed, the terms and conditions for being able to become a member of the prosecutor's office are not clearly explained, whether in a local text or a colonial archive, but at least they can be seen from the expressions of VOC officials at that time regarding prosecutors in other regions. In Memorie van Overgave dated July 29, 1714, Resident Cornelis Jongbloet, who had served as Cirebon resident, had revealed that those who were members of Jaksa Pepitu. They were the best and most experienced Javanese elected from each of the main districts. Then they were submitted to Batavia for approval or not by the Hooge Regeering. It seems unlikely that the chosen one is a bad person because it is not possible if these princes depend their legal fate on those who are less capable. ${ }^{15}$ The description Jongbloet certainly indicate a number of things that can be described as a prerequisite to become a member of the board of prosecutors, it is: (1) Jaksa Pepitu member was the mantri or leaders counted as the best and most virtuous among all enumerations that exist, (2) Jaksa Pepitu was the mantri who was proposed to be his representative by the Cirebon Princes, and (3) the Jaksa Pepitu was an official approved by the VOC leader in Batavia. Thus, the seven people selected at the beginning are people who are considered the most fulfilling these criteria than the other candidates mentioned before.

When viewed in terms of function and number, there is a similarity between the Jaksa Pepitu and Saptopapatti, a body in the Majapahit era consisting of seven Upapatti, a people who have competence in the field of law, in addition to the two kingdom Dharmadhyaksa. The Naerssen study based the data on the ancient manuscripts of Negarakertama and scripts on inscriptions in Trowulan, Bendosari, and Sidoteka concluded that because of his position the Upapatti belonged to the Pameget or noble

14 Hoadley, Selective Judicial Competence, pp. 19-20.

15 Cornelis Jongbloet, Memorie van Overgave, VOC 1857 (1714), pp. 108-9. 
people in the Majapahit Kingdom. ${ }^{16}$ Hoadley agreed on the relationship between the Prosecutor Pepitu and Saptopapatti on the basis of unique interrelationship, both in terms of the tasks carried out and of the number which consisted of seven chosen people. ${ }^{17}$ This relationship then made Hoadley stating that the concept of Jaksa Pepitu was a judicial body taken from the concept of Saptopapatti that had existed during Majapahit's heyday.

The similarity of the number of judges in the Majapahit and Cirebon eras, actually did not necessarily lead to the conclusion that the concept of court in the Cirebon era came from the concept of court in the Majapahit era. This can happen because there are still a number of things that are still unclear regarding the roles of the upapatti in the Majapahit era because at that time their function also still overlapped with the actions of the dhyaksa and adhyaksa in the kingdom. In addition, the Jaksa Pepitu also does not prioritize elementary matters in the Saptopapatti justice system, but is more influenced by the political interests originating from the court environment which at that time was divided into three power entities. The division must certainly make the three princes in power feel represented in the legal aspect, and therefore the number of seven prosecutors is more visible as an agency formed by considering the portion of each prince in the judicial field. When the power in Cirebon changes, the portion of Jaksa Pepitu membership division also changes. This happened when Kasepuhan was divided into two, namely Kasepuhan and Kacarbonan, so that Cirebon land was controlled by four princes. As a result of the dynamics, the number of representatives of prosecutors also changed, as recorded in the Pepakem Jaksa Pepitu manuscript: ${ }^{18}$

"Ing enggen punika panganggening Jaksa Pipitu, amiraos Kanjeng Sultan Anom jaksanipun kakalih. Kanjeng Sultan Sepuh jaksanipun kakalih. Kanjeng Sultan Carbon jaksanipun satunggal. Kanjeng Panembahan jaksanipun kakalib. Jaksa Pipitu paliwaranipun sakawan, para Sultan paliwaranipun sakawan, para Sultan paliwaranipun nyatunggal."

16 F.H. Van Naerssen, "De Saptopapatti: Naar aanleiding van een Tekstverbetering in den Nagarakrtagama", Bijdragen tot de Taal-, Land-en Volkenkunde, vol. 90, no. 1 (1933), pp. 239-58.

17 Hoadley, Selective Judicial Competence, p. 17.

18 Sudjana (tran.), Papakem Jaksa Pipitu, p. 7. 
This is the origin of Jaksa Pepitu, which is from Kanjeng Sultan Anom, the jaksa is two people, from Kanjeng Sultan Sepuh there are two people, from Kanjeng Sultan Carbon one person, and from Kanjeng Panembahan there are two people. Jaksa Pepitu comes from four neighborhoods, namely the four Sultan of Cirebon, who remain as oneness (nyatunggah).

\section{The Pace of Jaksa Pepitu in Handling Legal Cases}

Throughout its existence in the judicial and legal fields, Jaksa Pepitu has handled many cases. Unfortunately, the case records that have been handled by this council are rarely found in local sources, whether they are in the form of written traditions such as manuscripts or oral forms. The recordings of cases handled by the Jaksa Pepitu were actually obtained from colonial sources, among them came from the Dagh-Register van Batavia (Daily Records of Batavia Castle) and (most commonly found) from Overgekomen Brieven en Papieren (Letters and Reports Received/ Entered into VOC Central Headquarters in the Netherlands). These sources show how the dynamics of Jaksa Pepitu journey in enforcing the law in the Cirebon area.

From many cases that handled by the Jaksa Pepitu court, some of them can be used as examples of their actions in carrying out their duties as those responsible for legal matters. A number of examples of cases handled by this council can provide us with an overview about the position, independence and authority issue, that can be carried out by the collegial council of prosecutors as a symbol of law enforcement in Cirebon.

\section{Position}

The position occupied by the mantri in the Jaksa Pepitu office, turned out to indirectly contribute to strengthening their position in the hierarchical structure of administrative politics which led to the Compangnie's power. For example on the issue of this position, it can be seen from the case that confronts Panembahan Cirebon against Niti Praya and Wirat Maka. Panembahan referred here is Pangeran Wangsakerta, the third son of Panembahan Girilaya and the younger brother of Sultan Sepuh I and Sultan Anom I, Panembahan is the third prince. Whereas Niti Praya and Wirat Maka, are local elites who have territories and a 
number of cacab who in the days of their predecessors were under the authority of the Cirebon Sultanate in the Panembahan Ratu ruled. When the agreement was made between Francois Tak and the Cirebon Princes, Niti Praya and Wirat Maka were written as prosecutors from Panembahan. Regarding disputes involving both parties, it can be described as follows:

"In April 1693, Panembahan claiming that he owns the rights to about five hundred men who live in 12 villages which are under the authority of Niti Praya. Panembahan's recognition of the area was based on the fact that formerly Niti Praya's great-grandfather was a subordinate of Panembahan Ratu (Girilaya) or father of Panembahan Cirebon. Even Panembahan Girilaya conferred the title Tumenggung on the ancestors of Niti Praya and it has socially elevated his nobility and position degree. But even so, Niti Praya felt that his position had changed along with the political dynamics that occurred. When Cirebon was under the authority of Mataram, Niti Praya moved into Susuhan's subordinate, and when Cirebon was under the influence of the Company, Niti Praya and Wirat Maka included as local elites who signed the agreement and were even appointed as prosecutors from Panembahan". ${ }^{19}$

The condition which further complicates the situation is their position at odds with Panembahan. It was explained in the first part that Niti Praya and Wirat were two Jaksa Pepitu officials who actually served as Panembahan's representatives on the council. In addition, these two people belong to manca-pat/manca-pitu groups, which is referred to the mantri who has a free status of all Cirebon Princes claims. For Hoadley who studied this much, the status made them seem to have an equal position with the Javanese princes. ${ }^{20}$ In such circumstances, the court certainly should be held is Pradata court because the case was include noble people and has status as ruler of the territory.

Through the dispute between Panembahan Cirebon and Niti Praya and Wirat Maka, at least the position of Jaksa Pepitu in the government administration structure can be clearly seen so that we do not make mistakes when classifying these judges in the area management. However, the position of the prosecutor also influenced their independence in the

${ }^{19}$ Hoadley, Selective Judicial Competence, p. 28.

${ }^{20}$ For further information, see Mason C. Hoadley, Towards a Feudal Mode of Production: West Java, 1680-1800 (Singapore: Institute of Southeast Asian Studies with Nordic Institute of Asian Studies., 1994). 
effort to investigate and manage existing legal cases.

\section{Independence}

Regarding the independence of the Jaksa Pepitu in the midst of their efforts to maintain the legal superiority from the interventions of various parties that existed at the time, it was necessary to be put forward. The independence issue is important because it is closely related to the results of existing decisions. If there are parties who intervene the court conducted by the prosecutor's council, then the resulting decision can become flawed due to the lack of the principle of justice. To explore this independence, it was interesting to mention the case that occurred between Sura Patih and Gebang officials, which was more or less the following:

"In December 1690, there were three local elites who were in the power of the Gebang Principles and they diverted their direction of loyalty. Those elite were Sura Patih with his two colleagues. Before the case, these three leaders initially swore allegiance to Prince Gebang, then they intend to become subordinates of the Kasepuhan Sultanate. Not only that, the Gebang official were also sued by Sura Patih for being accused of a number of legal violations which included the theft of valuables things and the collection of their seven cacah (client) resources. After a thorough investigation, it was known that the accusation was baseless because it was discovered the fact that Sura Patih and his colleagues manipulated the debts of the seven slaves and promised them sweet things if they moved to become part of the Sultan Sepuh subject". ${ }^{21}$

If you look in this case, of course there is confusion faced by three jaksa from the Kasepuhan. However, the decisions they made were very influential on the comfort of the Sultan Sepuh because they indirectly became parties involved in the vortex of the dispute. If the decision they took was wrong and was considered detrimental to Kasepuhan, of course there were consequences they could get from the master. Not only loss of self-esteem and noble status, but it could also loss of life.

The initial fear of prosecutors that originating from Kasepuhan became evident because in the continuation of the case, the three prosecutors who had ties to the Sultan of Sepuh were reluctant to

${ }^{21}$ Hoadley, Selective Judicial Competence, p. 27. 
sign the decision of the majority of Jaksa Pepitu who won the Gebang Principality in the trial.

"After there is a guarantee that the value is equal to the value of the valuables allegedly lost and also the value of slaves, Jaksa Pipitu hear the lawsuit filed by Sura Patih against Gabang officials. After listening to the lawsuit and noting the facts of the law, the prosecutor's council split into two parts, where one party tried to win the Gebang official while the other tried to determine that Sura Patih was the winner of the trial. The prosecutors who supported Gebang's victory came from Sultan Anom and Panembahan prosecutors, while some other groups supporting the Sura Patih consisted of three prosecutors from the Sultan Sepuh. Even so, the prosecutor group that supports Gebang is far more numerous and therefore Sura Patih was decided as the guilty party because it was felt that it had revealed "eight (various) lies" in false allegations that could not be proven in real terms. The jayapattra document (letter of victory in the trial) was prepared for Gabang officials who were released in this case because they were not proven guilty at all". ${ }^{22}$

Basically, the independence referred to the context of the judiciary does not only revolve around the independence of judicial authority institutionally, but also the independence of the prosecutor personally. If institutional independence relates to the institution's position in the structure, the independence of the prosecutor is more to the position of the individual prosecutor in his life. In this case, the condition of the prosecutor must be free from any influence or pressure that comes from the people or other agency around him so that later the decisions taken are truly based on facts in the congregation, not based on the pressure given to him from other people. But it seems that the independence of the individual prosecutors is difficult to prove if they are dealing with their masters. Patron-client relations that connect prosecutors with the Cirebon Princes often make them stricken with confusion in the decision-making process. As in the case of Sura Patih with Prince Gebang above. The panel members who came from Kasepuhan finally chose to abstain from signing the decree which was detrimental to their wrestling. This shows that the independence of each of Jaksa Peptitu was not fully proven.

Properly, the seven prosecutors in the body should be representatives of the entire community when they take office. Theoretically, these ${ }^{22}$ Ibid. 
judges are no longer representatives of the Cirebon Princes, but God's representatives on earth because of their role as decision makers in the legal aspects that applied in the community. However, in practice, it is difficult to happen because it is invidual attachment prosecutors to patron-client relationships in traditional community structures allow their propensity for bias in the institutional structure of Jaksa Pepitu. If we look at the social and cultural reality, it seems that it was difficult to find any sign of a total independence of each individual council members who act as a law enforcer in Cirebon.

\section{Authority}

Jaksa Pepitu is a functional official by the Cirebon Princes (both from the Kasepuhan, Kanoman, and Panembahan neighborhoods) given orders to be their representatives in the implementation of the legal field. The seven members of the prosecutor's council are not arbitrary because each member has competence in the field of law and also has the capacity to assume the position of royal attorney. All Jaksa Pepitu member are from the mantri officials and have extensive skills and experience so that they can make themselves elected as the legal counsel of legal authority than other people. In accordance with the name and collegial nature, these seven prosecutors must have the same legal opinion and agree on one outcome in order to have a binding decision on the parties who litigate in the case they handle. ${ }^{23}$

The nature of the Jaksa Pepitu which demands an absolute and unanimous decision to make the seven as an inseparable entity, because if there is a prosecutor who does not have an agreement on a case then the results of what they have done are in vain. Jaksa Pepitu itself is a court system published in the Cirebon Pepakem customary book, and this council is also known as the Karta Court whose members consist of seven prosecutors. ${ }^{24}$

The authority and function of the Jaksa Pepitu in the management of the law in the Cirebon region was implicitly manifested in a number of agreements and contracts signed by the three parties from the Cirebon

${ }^{23}$ Ibid., p. 18.

${ }^{24}$ Satibi, 'Produk Pemikiran Hukum Islam di Kerajaan Islam Cirebon Abad ke-18 M: Studi atas Kitab Hukum Adat Pepakem', pp. 110-38. 
authorities together with high-ranking VOC officials, starting from the Contract Agreement in 1681, Agreement in 1685, Layang Ubaya in 1691, Surat Undhang-Undhang Cirebon in 1721, to Undang Nitih Cirebon in 1721$1723 .{ }^{25}$ In a number of these provisions, the Jaksa Pepitu has a function to act as a public prosecutor or executor of a claim, the perpetrator of the investigation in a particular case, the committee in charge of the court, the giver of input or legal insight, and the party who gives a decision that must be unanimous against a case. In addition, practically this council also has an arbitration function because they can provide peaceful efforts to parties involved in a case before carrying out the trial in court.

Although the function and authority of the prosecutor's council has been determined in the series of regulations that have been mentioned, in practice the task they are doing is always colliding with the curtains of local power and the Company. In a number of cases, their usefulness seemed to be limited because of the intervention carried out, both by the highest authority of Cirebon itself and by VOC officials who had certain interests in a case. For example, the Jaksa Pepitu session which had been produced in the Sura Patih case dealing with the Gebang official, in fact could not be carried out in accordance with the results that the majority of prosecutors had tapped because of the connection with the Kasepuhan Palace. Whereas in a number of cases related to certain economic interests, it will be very quickly decided by the results that benefit the VOC.

The Compagnie's intervention in the field of law continued to strengthen along with the increasing penetration of their power in the land of Cirebon. A number of provisions that were previously recorded in the local law book, and then deemed unsatisfactory for the VOC, will be immediately 'evaluated' by officials who instruct the relevant legal authorities. The results of the improvements will then be designed in the form of announcements, regulations, or government laws which are then socialized to the wider community.

\section{The Influence of Customary, Western and Islamic Law in the Jaksa Pepitu Council}

The existence of the Jaksa Pepitu in the field of law in the Cirebon

25 Brandes, "Eenige Officiele Stukken met Betrekking tot Tjerbon", pp. 448-9. 
region from the end of the seventeenth to the eighteenth centuries was also influenced by the various political dynamics and power that occurred. In the beginning, when the hegemony of the VOC power was still limited, this council was very strong in the elements of its local customs because the origin of the law which was used as a reference came from the legal text that had previously existed in the region. Lukito revealed that the law that had developed before the existence of foreign laws, ${ }^{26}$ came from the chthonic (Customary Law), which emerged from the local wisdom of the community. Then, since the strength of the Company had become stronger and had a political influence on the highest authorities of Cirebon, the journey of the seven elected prosecutors had also undergone a change because of the many legal articles included in their manual, its characteristics were Dutch or West. The influence of Islam can penetrate into Jaksa Pepitu because of the intervention of the VOC who saw the importance of applying the law in accordance with the conditions of the majority community who lives as the Muslims. In this context, the Hooge Regeering or VOC government apparently did not enforce the (western) laws they adopted, and instead accommodated customary and Islamic laws.

In order to make the discussion about the influence of various legal elements to the Jaksa Pepitu more clear, it will be described as follows:

\section{Customary Law}

A document, containing the text of the agreement between Cirebon and the VOC dated January $7^{\text {th }}, 1681$ in the National Archives of the Republic of Indonesia (ANRI) shows that seven of the nine local rulers of Cirebon who at that time had their signatures signed, were known to the Cirebon public as the Jaksa Pepitu, they are: Prince Wangsakerta, Raksanagara, Purbanagara, Anggadiraksa, Anggadiprana, Anggaraksa, and Nayapati. ${ }^{27}$ Although the names have been recorded

26 The Chthonic term is derived from the Greek term, khthon or khthononos which can be interpreted as "earth". Read, Ratno Lukito, Tradisi Hukum Indonesia (Yogyakarta: Teras, 2008), p. 3.

27 The text of Cirebon Archives Collection, Agreement, no. 38.3 (Jakarta: ANRI, 1681); Cirebon Archives Collection, Agreement, no. 38.4 (Jakarta: ANRI, 1681). 
in the agreement, ${ }^{28}$ their role in legal matters has not been written clearly because the agreement only addresses political issues (diplomatic relations), security (troop gathering and building of loji or castle), and the economy (trade commodities monopoly). ${ }^{29}$

When the name of Jaksa Pepitu body first appeared as a court of law in Cirebon in an agreement with the VOC in 1685, it was not clear what could be used as a source for them to conduct a trial and decide a case. Apparently, the law that had previously worked in the area was temporarily maintained, because the VOC did not have a planned policy regarding the matter. In the agreement, the Jaksa Pepitu was referred to Mantri or Wong Pepitu. They deal with legal issues involving the three princes (ratu katiga sanak) who ruled Cirebon. ${ }^{30}$

Legal sources that were previously used so-called as Javanese law by Hoadley. According to him, these laws were never formally promulgated until then the law began to be displaced due to the influence of Western law. That fact caused by Java more legal orientation aims to maintain or restore social harmony than to give absolute decisions with an emphasis on what is right and what is wrong. The number of texts identified as part of Javanese law is Jaya Lengkara, Medang Kamulan, Surya Alam, Senopati Jimbun, Jugul Muda, Sunduk Prayoga, Religion, Adigama, Purwadhigama, and Kutara Manawa. ${ }^{31}$ The six texts mentioned earlier are texts that reflect great places and individual figures in the past who have wisdom and greatness in life. While the rest, the titles of the texts implicitly indicate the emphasis on religious values.

28 The agreement document consists of two texts, written in two different types of characters and languages. The text on the left, was Arabic with Malay language, while the text on the right was Dutch with Latin script. Although the characters and language were different, the two texts have the same meaning and understanding because the contents are the same.

29 E.C.G. Molsbergen, "Uit Cheribon's Geschiedenis", in Gedenkboek der Gemeente Cheribon, 1906-1931 (Bandoeng: Gedrukt bij de N.V.A.C. Nix, 1931), pp. 27-35.

30 In article 8, said that: "supaya aja papadon, kalayan pitena ing prakara sawidjiwidji, ayun agawe pareta sewang-sewangan, dipun patut, ratu katiga sanak, boya kena dewek, angukumaken, kalayan tani karana iku patut, agawe witjara, maring mantri katiga sanak, titi”. See more, the script of the December 4th, 1685 Agreement (between Cirebon and the Dutch Company), published in the writing of a Dutch scholar, Brandes, "Eenige Officiele Stukken met Betrekking tot Tjerbon”, pp. 467-70.

31 Hoadley, Selective Judicial Competence, pp. 69-70. 
Judging from the number of defaults, the prosecutor's council also looks very much at its locality. The number of prosecutors who were seven people were believed to have come from bodies that had existed in the Pajajaran era (Mantri Pipitu) and Majapahit (Saptopapatti). Although the number of mantris or regional authorities under the authority of the three princes was more than seven, but only seven of them who were chosen to take care of legal matters. ${ }^{32}$ In addition, in the view of the Nusantara cosmology, there is a belief that the number seven is a symbol of something infinite, as in the seventh heavenly expression, the seventh generation, and so on. The use of the name Jaksa Pepitu itself shows the resilience of local terms and languages when there is a strong intervention from outside cultures on local matters.

The patron client relationship that binds Jaksa Pepitu to Cirebon Princes, also shows that these local habits can still survive and influence the existence of the body that in charge of the law. In fact, the relationship between the gusti-kawula was increasingly felt, when the decisions involved influenced the interests of one of the Cirebon princes. So it can be ascertained that there is a tendency for results or court decisions that are not satisfactory, especially for those who are opposed to the Cirebon rulers.

\section{Western Law}

Recognition of the influence of Western law on Jaksa Pepitu is difficult to recognize for some people, especially those who believe that their ancestors were free and did not have any relation or cooperation to the VOC. But even so, the relationship cannot be ignored, because some evidence actually shows that the influence coming from the West does not only infiltrate the economic aspect, but also the law.

In article 20 of the 8 September 1688 Agreement between Cirebon and the VOC, we can see that the western influence was already very large

32 In 1685, the seven Cirebon Jaksa Pepitu consisted of three Sultan Sepuh prosecutors (saking Sultan Sepub titiga), two Sultan Anom prosecutors (saking Ratu Anom kakalih), and two Panembahan Wangsakerta prosecutors (saking Pangeran Topati kakalih). They have the authority to talk about legal cases in Cirebon (kang lungguh ing dalem bitjara iku wong pipitu). The text of the December 4th, 1685 Agreement (between Cirebon and the Dutch Company), published in the writing of a Dutch scholar, Brandes, "Eenige Officiele Stukken met Betrekking tot Tjerbon”, p. 469. 
in Cirebon legal matters because the Company was the decisive adviser on the appointment of Jaksa Pepitu officials. ${ }^{33}$ Moreover, in the Jaksa Pepitu body, the influence that came from Western law was manifested in the results of their work in the form of a legal guide book that they held. In addition to the systematic and logical manuscript arrangement, it is also seen from the various confessions in the book regarding the superiority of the VOC over Cirebon nobles. We can easily find threats coming from Batavia if there are violations committed by the community, and the articles were written by those seven prosecutors.

It should be understood together that the drafting of such a legal book only occurred when the VOC had come to the archipelago and gave orders for its manufacture. Before that, there was no unification of legal sources, and there were decision-making sources separate from each other. Legal cases that occurred in previous times show that the determination of decisions is often based on collective agreement rather than legal arguments written. For example, in the case of the death sentence of Syekh Lemahabang by the Wali Sanga Board in Cirebon, the council gave decisions not based on certain legal books or manuals, but based on the joint decisions of the Wali Sanga board. ${ }^{34}$ Accordingly, the order from the VOC to formulate a clear legal guidebook is evidence of western influence to the legal issues of native peoples.

33 See article 20, it was written that: "... zo veel volk te zamen zullen doen wijtkeeren en ter handt stellen als bij onderzoekinge van de gewone zeeve Javaensche regters off mantrijs der drie princen met advijs van s'Comps. rezident...”. The text of the September 8th, 1688 Agreement (between Cirebon and the Dutch Company), published in the writing of a Dutch scholar, Ibid., p. 477.

${ }^{34}$ In the story of the script Carita Purwaka Caruban Nagari (now kept in the Sri Baduga Museum Bandung, West Java), which was completed by Prince Arya Carbon in 1720, it was said that the execution of Shaykh Lemahabang was carried out as follows: “...ngaranira hana pwa Seh Le (maha)bang ika Bagdad asalira Si' ah Muntadar panganutanira / ya tamolah ing Pangging Jawa Wetan engke mangajarakna agama ring Ki Ageng lawan janmapadha / tatapinyan mangkana pra sang kamstu ing / / Jawa Dwipa nyatruwani sira / makanimitta ika Seh Lema(ha)bang pinejahan dengn sira Susubunan Kudus lawan Kanthanaga sanjata ika gadabira Susubunan Jati Purba..." (His name was Syekh Lemahabang who came from Baghdad, he was a follower of the Shia Mu'tadar. He lives in Pengging, East Java, and taught religion matters to $\mathrm{Ki}$ Ageng and his citizens. However, the Wali Sanga board in Java were hostile to him, therefore Syeh Lemahabang was executed by Susuhunan Kudus with Kris Kanthanaga [one of Susuhunan Jati Purba’s main heirloom]). 
In addition to the ideal level which is in the form of a guideline, the influence of western law is also seen from various technicalities of the implementation of the trial conducted by prosecutors. An example, in the days of Sunan Gunung Jati, a legal matter was sufficiently decided at the mosque by a judge from the member of Wali Sanga council. But in the duty of the Jaksa Pepitu era, precisely in $1768,{ }^{35}$ there was a special legal hearing place in Kejaksan (the name of place to the west of the Sepuh, Anom, and Panembahan palaces) and the process was administered by four clerks who came from each of the sultanates. Obviously, this is the new thing in the technical trial whic was influenced by the legal habits that existed in the European court tradition.

However, all this can not only be concluded from one or two sessions, but from many congregations at once. Therefore, further comprehensive and comprehensive research on this matter, is needed.

\section{Islamic Law}

The influence derived from Islamic law against the Prosecutor of Pepitu can be seen as a legal authorization which leads to the top leadership of the government. The obligation to obey the 'ulil amr' in Islam, was also seen in the Jaksa Pepitu council when they found a deadlock in dealing with legal cases handled. The stalled road will surely be left to the policy of the Sultan of Cirebon or the VOC ruler as the highest leader in the government structure. This was clearly noted in the 1685 treaty, an agreement that could be said as the basis of the Jaksa Pepitu existence. In article 12 of the agreement it was said that: “...yen wonten sadaleming witjara iku prakara ingkang awrat, ora kena pinegat maka matur sewang-sewangan, ing gustine mantri pipitu, iku kang matur ing gustine, tit?" ${ }^{36}$ (If the verdict cannot be produced by the mantris or jaksas, then all the conclusions of the legal

35 The 'Pepakem Jaksa Pepitu' manuscript is probably a compilation legal book copy given by the VOC government to the Kanoman Kraton. In the colophon of the manuscript, it is known that the manuscript was written in 1768. The description as follows: "Punika cucuthatan saking serat mupangatipun Kangjeng Sultan sakawan sarta tuan Petor ing nagari Carbon. Waktu ing dinten Senen, tanggal ping wolulas, ing sasih April lagi taun 1768". See, Sudjana (tran.), Papakem Jaksa Pipitu, p. 17.

36 The script of the December 4th, 1685 Agreement (between Cirebon and the Dutch Company), published in the writing of a Dutch scholar, Brandes, "Eenige Officiele Stukken met Betrekking tot Tjerbon”, p. 469. 
problem were returned to the three princes).

The principle of legality and the principle of equality before the law also shows the existence of elements of Islam in carrying out the duties of the Pepitu Prosecutors. In Islam, it is clear that those who violate the provisions in the $\mathrm{Al}$-Qur'an and Hadith are people who deserve punishment, as well as what happened in the trial process of the Cirebon prosecutors. These jaksas were trying their best to carry out their duties, which is certainly in accordance with the teachings of the religion they embraced. They glorify the book of Pepakem which is a reference for the execution of punishment for those who commit violations.

Referring to Islamic sources is something that cannot be avoided by lawyers in Cirebon, since beyond the fact that most of their people are Muslims who live within the rules of Islam, traditional sources (such as manuscripts and oral history or tradition) explicated that the regional heads (local leaders) of the Cirebon community are those who have gained the trust from the main leader (Sunan Maulana Jati) and converted to Islam. According to Carita Purwaka Caruban Nagari manuscript, regional leaders who had submitted to and embraced Islam in Cirebon during the Sunan Jati era, some of them: Pangeran (Prince) Kuningan, Pangeran Sabakingkin, Pangeran Cirebon, Pangeran Pasarean, Pangeran Kejawanan, Pangeran Welang, Pangeran Luhung, Pangeran Makdum, Pangeran Raja Laut, Pangeran Jagasatru, Pangeran Cucimanah, Dipati Suranenggala, Tumenggung Jagabaya, Tumenggung Jaya Orean, Buyut Gresik, Ki Gede Jatimerta, Ki Gede Babadan, Ki Gede Mundu, Ki Gede Ujunggebang, Ki Gede Sura (Ki Gede Tegalgubug), Ki Gede Japura, Ki Gede Ender, Ki Gede Buntet, Ki Gede Selapandan, Ki Gede Trusmi, Ki Gede Luragung, Dipati Arya Kuningan, Dipati Anom, Dipati Cangkuang, Dipati Sukawiyana, Dipati Selanunggal, Ki Waruanggang, Padillah, Ki Gede Tedeng, Ki Gede Tameng, Ki Anggaraksa, Ki Gede Paluamba, Raden Sepat, Dipati Keling, Ki Gede Sembung, etc. ${ }^{37}$ It is possible that the members of the Jaksa Pepitu were among the descendants of them (the regional heads during the reign Sunan Jati).

37 Atja, Carita Purwaka Caruban Nagari: Karya Sastra sebagai Sumber Pengetabuan Sejarah (Bandung: Pusat Pengembangan Permuseuman Jawa Barat, 1986), pp. 189-90. 


\section{E. Concluding Remarks}

The legal fields in Indonesia have experienced a very long historical process. Various cultures and traditions have contributed to Indonesian law so that it can show its authenticity, it can show its western face and Islam. These three faces can be seen in the Jaksa Pepitu, a prosecutor's council that has existed in the history of the Cirebon Sultanate.

This study provides a little picture of this collegial council. Some important findings that can be extracted from this study include: First, the origin of the Jaksa Pepitu can be seen from the interests of the Cirebon princes in the legal field in their territory. Even so, the number seven of the prosecutors' number seems to be inspired by many things, ranging from numbers that cosmologically represent infinity to the number of members of similar bodies that have existed in previous times; Second, the Jaksa Pepitu's work in the legal history of the Cirebon Sultanate shows that their position can actually be said to be equivalent to the Cirebon princes. This can happen because a court is a representative of God on earth and the good and bad of litigants are in their hands. Even so, their independence should be further investigated because there is a tendency for partiality when legal cases are related to the Cirebon prince who has a client patron relationship with the member of the agency. As for the authority they have, revolving around the matter of filing a lawsuit, the media of arbitration as it can be a peacemaker for parties who litigate before conducting a hearing, legal counsel, and providing input in various matters relating to the issue of rule of law in the community; Third, the existence of this body cannot be separated from the influence of customary law, Western law, and Islamic law. It can be said that one form of the legal interferences existed in the form of the Jaksa Pepitu.

Overall, this research provides a statement that the study of legal history that occurred in previous times is a very interesting challenge to deal with. Institutions responsible for law, technical and trial and court processes, patterns of conflict resolution, which existed at the time became the root of various matters in the current law. But unfortunately, the attraction is very little interest from scholars to research it. Until now, the researchers of legal history in Indonesia can still be counted on the fingers. Whereas this field is one of the fields that has always been a hot topic of discussion among the Indonesian people, especially 
Tendi, Djoko Marihandono \& Abdurakhman

when various legal cases that show injustice arise and surfaced. Thus, the recommendations of this study are the need to conduct further research on the study of legal history, especially local laws that are characteristic of every ethnic group in Indonesia. 


\section{BIBLIOGRAPHY}

Atja, Carita Purwaka Caruban Nagari: Karya sastra sebagai sumberpengetabuan sejarah, Bandung: Pusat Pengembangan Permuseuman Jawa Barat, 1986.

Brandes, J., "Eenige Officiele Stukken met Betrekking tot Tjerbon”, TBG, vol. 37, 1894, pp. 449-88.

Cirebon Arcbives Collection, Agreement, no. 38.3, Jakarta: ANRI, 1681.

----, Agreement, no. 38.4, Jakarta: ANRI, 1681.

Cornelis Jongbloet, Memorie van Overgave, VOC 1857, 1714.

Graaf, H.J. de, Runtubnya Istana Mataram, Jakarta: Grafiti Pers, 1987.

Halim, Abdul, Peradilan Agama dalam Politik. Hukum di Indonesia: Dari Otoriter Konservatif menuju Konfigurasi Demokratis-Responsif, Jakarta: Raja Grafindo Persada, 2000.

Hardjasaputra, Sobana and Tawalinuddin Haris (eds.), Cirebon Dalam Lima Zaman: Abad ke-15 bingga Pertengahan Abad ke-20, Bandung: Dinas Pariwisata dan Kebudayaan Provinsi Jawa Barat, 2011.

Hazeu, G.A.J. (ed.), “Tjeribonsch Wetboek van het jaar 1768 (Pěpakĕm Tjërbon)", VBG, vol. 55, 1905, pp. 1-187.

Hoadley, Mason C., Selective Judicial Competence: The Cirebon-Priangan Legal Administration, 1680-1792, Ithaca, N.Y: Southeast Asia Program Publication, Cornell University, 1994.

----, Towards a Feudal Mode of Production: West Java, 1680-1800, Singapore: Institute of Southeast Asian Studies with Nordic Institute of Asian Studies., 1994.

Hoadley, Mason C., Islam dalam Tradisi Hukum Jawa \& Hukum Kolonial, trans. by Jamil Gunawan, Yogyakarta: Graha Ilmu, 2008.

Lukito, Ratno, Tradisi Hukum Indonesia, Yogyakarta: Teras, 2008.

Mason C. Hoadley and M.B. Hooker, An Introduction to Javanese Law: A Translation of and Commentary on the Agama, Tucson, Arizona: University of Arizona Press, 1981.

Molsbergen, E.C.G., "Uit Cheribon's Geschiedenis", in Gedenkboek der Gemeente Cheribon, 1906-1931, Bandoeng: Gedrukt bij de N.V.A.C. 
Tendi, Djoko Marihandono \& Abdurakhman

Nix, 1931.

Satibi, Ibi, "Produk Pemikiran Hukum Islam di Kerajaan Islam Cirebon Abad ke-18 M: Studi atas Kitab Hukum Adat Pepakem", Saintifika Islamica: Jurnal Kajian Keislaman, vol. 1, no. 02, 2017, pp. 110-38.

Sudjana, T.D. (tran.), Papakem Jaksa Pipitu, Jakarta: Departemen Pendidikan dan Kebudayaan, Proyek Penerbitan Buku Sastra Indonesia dan Daerah, 1981.

Tresna, Raden, Peradilan di Indonesia: Dari Abad ke Abad, Jakarta: Pradnya Paramita, 1978.

Van Naerssen, F.H., "De Saptopapatti: Naar aanleiding van een tekstverbetering in den Nagarakrtagama", Bijdragen tot de Taal-, Landen Volkenkunde, vol. 90, no. 1, 1933, pp. 239-58.

Zaedin, Muhamad Mukhtar and Panji Darussalam (eds.)Irianto, Bambang and Tarka Sutarahardja (trans.), Sejarah Cirebon: Naskah Keraton Kacirebonan: Alih Aksara dan Bahasa Teks KCR 04, Yogyakarta: Deepublish, 2013. 